Jerzy AdAmCZyK

\title{
DiECEZJALNY URZĄD KATECHETYCZNY
}

\section{Wstęp}

W adhortacji apostolskiej Catechesi tradendae papież Jan Paweł II przypomniał biskupom ich obowiązki w dziedzinie katechizacji, z racji tego, że są oni w swoich Kościołach pierwszymi katechetami. Biskupi winni pamiętać, że troska o rozwój żywej i owocnej katechezy nie może ustępować żadnej innej trosce, jakakolwiek by ona była. Mają sprawować najwyższe kierownictwo katechizacji w swoich diecezjach ${ }^{1}$.

Redaktorzy Dyrektorium Ogólnego o Katechizacji podkreślają że troska o katechizację winna prowadzić biskupa do podjęcia najwyższego kierownictwa katechizacji w Kościele partykularnym². Żeby jednak biskup był w stanie skutecznie pełnić najwyższe kierownictwo katechizacji w swojej diecezji, winien dobrać „sobie doświadczonych i godnych zaufania współpracowników" ${ }^{\prime 3}$. Owi współpracownicy biskupa w koordynacji działalności katechetycznej w diecezji to przede wszystkim Referat (Wydział) katechetyczny (Officium catechisticum)4, który grupuje zespół

* Ks. dr hab., Wyższe Seminarium Duchowne w Radomiu; e-mail: ksjerzyad@wp.pl.

${ }^{1}$ Ioannes Paulus P.P. II, Adhortatio Apostolica, Catechesi tradendae (16 octobris 1979), nr 63, „Acta Apostolicae Sedis” 1979, s. 1277-1340, tekst polski: W. Kubik (red.), Katecheza po Soborze Watykańskim II w świetle dokumentów Kościoła, cz. II, Warszawa 1985, s. 146-217 (dalej: CT).

${ }_{2}$ Congregazione per il Clero, Direttorio Generale per la Catechesi (15 agosto 1997), nr 223, Libreria Editrice Vaticana 1997, tekst polski: Kongregacja ds. Duchowieństwa, Dyrektorium Ogólne o Katechizacji, Poznań 1998 (dalej: DOK).

${ }^{3} \mathrm{CT}, \mathrm{nr} 63$.

${ }^{4}$ DOK, nr 265. „Podstawowa i bezpośrednia odpowiedzialność biskupa za dzieło ewangelizacji i katechizacji w jego Kościele realizuje się praktycznie poprzez diecezjalny 
osób - kapłanów, zakonników i świeckich posiadających odpowiednie kompetencje i rzeczywiście biegłych w swoich dziedzinach ${ }^{5}$. Officium catechisticum jest „narzędziem, którym posługuje się biskup - głowa wspólnoty i wykładowca nauki - dla kierowania całą działalnością katechetyczną w diecezji"6.

Kodeks Prawa Kanonicznego z 1983 r. ${ }^{7}$ daje możliwość powołania przy Konferencji Episkopatu urzędu katechetycznego, którego głównym zadaniem byłoby świadczenie pomocy poszczególnym diecezjom w sprawach katechezy $^{8}$. Kodeks nie wspomina jednak o Referacie (Wydziale) katechetycznym w diecezji, mimo tego prawo partykularne i praktyka kościelna taki urząd przewidują i tego rodzaju instytucje od lat funkcjonują.

Powstaje zatem pytanie: jak doszło do powstania diecezjalnego $\mathrm{Wy}$ działu katechetycznego? Czy wspomniany urząd kurialny jest nadal obowiązkowy z prawa powszechnego? Jeśli tak, to jakie są jego zadania? Odpowiedź na postawione pytanie stanie się przedmiotem niniejszego przedłożenia.

\section{Diecezjalny Wydział katechetyczny - owoc kształtowania się przepisów dotyczących nauczania katechetycznego}

Katechizacja jest ze swej istoty aktem eklezjalnym. Prawdziwym podmiotem katechezy jest Kościół, który, kontynuując posłannictwo Jezusa, kierowany przez Ducha Świętego, czuje się posłany, by być nauczycielem wiary. Kościół wiernie zachowuje Ewangelię, głosi ja, celebruje, przeżywa i przekazuje w katechezie tym wszystkim, którzy zdecydowali się pójść za Jezusem Chrystusem9. Fundamentalnym celem katechezy jest dopro-

urząd katechetyczny". Ufficio catechistico diocesano e servizio diocesano per il catecumenato: natura pastorale e documentazione, http://www.fermodiocesi.it [dostęp: 10.10.2015 r.].

${ }^{5}$ Por. DOK, nr 267.

${ }^{6}$ DOK, nr 265.

7 Codex Iuris Canonici auctoritate Ioannis Pauli PP. II promulgatus (25 ianuarii 1983), „Acta Apostolicae Sedis” 75 (1983), part II, s. 1-317; Kodeks Prawa Kanonicznego, przekład polski zatwierdzony przez Konferencję Episkopatu, Poznań 1984 (dalej: KPK).

${ }^{8}$ Kan. 775 § 3 KPK; por. DOK, nr 269. Taki urząd, pod nazwą Ufficio Catechistico Nazionale, istnieje przy Konferencji Episkopatu Włoch. Conferenza Episcopale Italiana, Incontriamo Gesù. Orientamenti per l'annuncio e la catechesi in Italia (29 giugno 2014), Presentazione, „Notiziario CEI” 2014, nr 4, s. 198-289 (dalej: IGO).

${ }^{9}$ Por. DOK, nr 78. 
wadzenie kogoś nie tylko do spotkania z Jezusem, ale do zjednoczenia i głębokiej z Nim zażyłości ${ }^{10}$.

W ciągu wieków wraz z powszechnym wprowadzeniem praktyki chrztu dzieci zaczęło wzrastać w Kościele coraz większe zainteresowanie chrześcijańską formacją pochrzcielną. Elementarna formacja chrześcijańska dzieci była następnie kontynuowana i uzupełniana przez regularne kształcenie religijne dorosłych. Sobór Trydencki przyznaje systematycznej katechezie fundamentalną rolę $\mathrm{w}$ formacji chrześcijańskiej ${ }^{11}$.

We wczesnym i przede wszystkim w późniejszym dzieciństwie formacja chrześcijańska zabezpieczana przez rodzinę była wzbogacana przez nauczanie religijne przekazywane w szkołach klasztornych, parafialnych i biskupich, tak powszechnych w średniowieczu. Wraz z Soborem Trydenckim powstał obowiązek promowania w każdej parafii $w$ niedziele i dni świąteczne elementarnego kształcenia religijnego dla wszystkich dzieci. W ten sposób katecheza dzieci, już obecna w pewnych Kościołach lokalnych, stała się oficjalnym zadaniem obowiązującym we wszystkich parafiach. Uprzywilejowanym narzędziem kształcenia dzieci był katechizm - streszczenie doktryny chrześcijańskiej w pytaniach i odpowiedziach ${ }^{12}$.

Rodzice byli wspierani przez Kościół w ich misji wychowawczej na różne sposoby. $W$ przepowiadaniu przekazywano rodzicom treści, które winni przekazywać dzieciom oraz sposób prowadzenia życia cnotliwego. Ponad to oferowano wiernym świeckim podręczniki życia chrześcijańskiego, gdzie zamieszczano zasady i wskazówki, jak: "osiągnąć posłuszeństwo", "uczyć modlitwy i fundamentalnych prawd doktryny chrześcijańskiej”, ,"zaangażować dzieci w obrzędy religijne”. Spowiedź, przynajmniej

${ }^{10}$ Por. DOK, nr 81.

${ }^{11}$ Conferenza Episcopale Italiana, L'iniziazione cristiana. Orientamenti per l'iniziazione dei fanciulli e dei ragazzi dai 7 ai 14 anni. Nota pastorale del Consiglio Episcopale Permanente 1999 (23 maggio 1999), nr 13, „Notiziario CEI” 1999, nr 7, s. 253-283 (dalej: OPI). „Biskupi będą troszczyć się, aby przynajmniej w niedziele i w dni świąteczne w każdej parafii dzieci były pilnie pouczane przez tych, którzy są do tego zobowiązani, o podstawach wiary i o posłuszeństwie w tym, co dotyczy Boga i ich rodziców". I Decreti del Concilio di Trento, Testo divulgativo con annotazione delle fonti, Sessione XXIV, Decreto di riforma, can. 4, Roma 2005, s. 124 .

${ }^{12}$ OPI, nr 13. Tym, którzy zaniedbywaliby obowiązek katechezy parafialnej Sobór Trydencki groził cenzurami. I Decreti del Concilio di Trento, Testo divulgativo con annotazione delle fonti, Sessione XXIV, Decreto di riforma, can. 4, s. 124. W konstytucji Benedykta XIV Etsi minime poleca się używanie w katechizacji ludu katechizmu kardynała R. Bellarmina. Benedicto XIV, Constitutio Etsi minime (7 februarii 1742), nr 17, [w:] P. Gasparri, I. Seredi (red.), CIC Fontes - Codicis Iuris Canonici Fontes, vol. I, Roma 1926, s. 715-720. Tenże papież, jako metodę sprawdzania wiadomości katechetycznych u dzieci, poleca zadawanie jasnych i prostych pytań. Konstytucja Etsi minime, nr 17. 
roczna, była okazją aby uświadomić rodzicom ich odpowiedzialność, zadać pytanie, w jaki sposób spełniają swoje zadanie wychowania dzieci. Rodzice byli wspomagani w ich misji edukacyjnej przez chrzestnych, powołanych także do formowania dzieci. Obowiązki wychowawcze rodziców i chrzestnych wynikały z sakramentu chrztu. Przypominano, że rodzice i chrzestni mają wychować dzieci w wierze katolickiej, ponieważ ci pierwsi je urodzili i Bóg dał je im, a ci drudzy, ponieważ stali się gwarantami ich wychowania religijnego ${ }^{13}$.

Papieże, najwyżsi zwierzchnicy i nauczyciele wiary katolickiej, zawsze troszczyli się o to, by lud Boży był pouczany przez nauczanie katechetyczne $^{14}$. O obowiązku duchownych przyjęcia odpowiedzialności katechetycznej mówi konstytucja Benedykta XIV Etsi minime. Papież przypomina, że szczególnym zadaniem biskupów jest przedstawianie w sposób jasny i metodyczny doktryny chrześcijańskiej. Powinni oni poświęcić się tej pracy, szczególnie ważnej, z całą troską i pilnością. Będą oni spełniać to zadanie także poza czasem wizytacji pasterskiej, przekazując zdrową doktrynę wiernym, dokonując tego poprzez pytanie chłopców i dziewcząt o rzeczy wysłuchane oraz będą ilustrować swoimi słowami tajemnice wiary. To będzie bardzo pożyteczne dla trzody (owczarni) jemu powierzonej, i jego przykład będzie pobudzać innych do uprawiania ze wszystkich sił winnicy Pana Zastępów. Tak jak wielcy biskupi, Karol Boromeusz czy Franciszek Salezy, nie będąc w stanie osobiście wykonać tego zadania przeznaczali do wypełniania tego poważnego obowiązku wikariuszy wybranych spośród kanoników albo kapłanów, tak biskupi dla wychowania młodzieży zgodnie z podstawowymi prawdami wiary i obowiązkami wynikającymi z religii mają wybierać swoich zastępców do tego zadania. Owi zastępcy, szczególnie proboszczowie i wikariusze, mają wypełniać dwa podstawowe obowiązki nałożone na duszpasterzy przez Sobór Trydencki: pierwszy - przepowiadanie słowa Bożego w dni świąteczne i drugi - pouczanie o podstawowych prawdach wiary dzieci i tych, którzy nie znają Prawa Bożego ${ }^{15}$.

Benedykt XIV zwraca uwagę nie tylko na konieczność katechezy dzieci i młodzieży, ale także, zauważając ignorancję religijną ludzi dorosłych i osób w podeszłym wieku, nakazuje biskupom naprawić te braki stosując

${ }^{13}$ OPI, nr 14.

${ }_{14}$ Zob. Sacra Congregatio Concilii, Decretum Provido sane consilio (12 ianuarii 1935), „Acta Apostolicae Sedis" 1935, s. 146 (dalej: PS). Trzeba pamiętać, że na mocy tego dekretu zarządzono, jeśli to możliwe, powołanie w każdej diecezji diecezjalnego urzędu katechetycznego (nr 1, s. 151); por. DOK, nr 265.

${ }^{15}$ Benedicto XIV, Constitutio Etsi minime, nr 2-5; por. PS, II b. 
odpowiednie środki zaradcze ${ }^{16}$. Papież zabrania proboszczom dopuszczania do sakramentów Eucharystii i bierzmowania tych, którzy nie mają odpowiedniego przygotowania katechetycznego ${ }^{17}$. Konstytucja Benedykta XIV Etsi minime zobowiązuje duszpasterzy, aby przed dopuszczeniem do sakramentu małżeństwa sprawdzili u nupturientów poprzez odpowiednie, precyzyjne pytania, czy mężczyzna i kobieta są świadomi tego, co jest konieczne do zbawienia. Biskup bowiem nie może tolerować ignorancji religijnej u kandydatów do małżeństwa i ma wzywać duszpasterzy do wypełniania ich zadań $\mathrm{w}$ tej materii, a zaniedbujących je winien ukarać18.

Decretum Provido sane consilio zwraca uwagę na ważny dokument Piusa X, mianowicie encyklikę Acerbo nimis ${ }^{19}$. Papież, po wyliczeniu korzyści wynikających z nauczania katechezy, słusznie wnioskuje, że przyczyną wielkiego osłabienia wiary jest zapomnienie lub zaniedbanie obowiązku nauczania doktryny chrześcijańskiej. Stąd ustanawia prawa, które zobowiązują do nauczania doktryny katolickiej chłopców i dziewczęta, młodzież i dorosłych ${ }^{20}$.

Encyklika Acerbo nimis nakazuje, aby każdy proboszcz pouczał wiernych w kwestiach religijnych i postanawia:

1. Wszyscy proboszczowie, i ogólnie ci wszyscy, który pracują w duszpasterstwie, we wszystkie niedziele i święta roku, bez żadnego wyjątku, mają przez godzinę nauczać katechizmu chłopców

16 Tamże, nr 8; zob. nr 14.

17 Tamże, nr 9. Papież zabrania proboszczom dopuszczania do bierzmowania tych, którzy nie znają fundamentów wiary i doktryny oraz znaczenia i mocy tego sakramentu (tamże). Według konstytucji Etsi minime obowiązek znajomości prawd wiary i warunków sakramentu jest konieczny także do dobrej spowiedzi. Tamże, nr 12.

18 Tamże, nr 11.

19 Pius PP. X, Litterae encyclicae Acerbo nimis (15 aprilis 1905), "Acta Sanctae Sedis” 1904-1905, s. 613-625.

${ }^{20}$ PS, 146. Pius X w Acerbo nimis pisze, że znajomość spraw religijnych jest nie tylko światłem umysłu, ale również przewodnikiem i bodźcem dla woli (nr 4). Papież pochwala nauczanie katechizmu. Przypomina i zobowiązuje kapłanów do prowadzenia katechizacji mówiąc, że „każdy kapłan ma obowiązek pouczania wiernych” (nr 6-7). Szczególnie obowiązek ten dotyczy proboszczów, którzy w myśl uchwał Soboru Trydenckiego mają przynajmniej w niedziele i święta bardziej uroczyste pouczać lud o prawdach religijnych, i codziennie, albo przynajmniej trzy razy w tygodniu, mają to czynić także w świętych czasach Adwentu i Wielkiego Postu. Ci, którzy mają przyjąć sakramenty winni być pouczani o nich, stosownie do ich możliwości i uzdolnień, prostym i jasnym językiem. Papież przypomina, cytując słowa Benedykta XIV z jego encykliki Etsi minime, że wyjaśnianie Ewangelii i katechizmu to dwa wyraźne obowiązki proboszcza nakazane przez Sobór Trydencki. Pius X wyraża dezaprobatę wobec tych, którzy „w celu zmniejszenia swojego wysiłku przekonuja, że wyjaśnianie Ewangelii może zastąpić nauczanie katechetyczne” (nr 8-9). 
i dziewczynki w tym, w co każdy musi wierzyć i czynić, aby się zbawić.

2. Ci sami, w określonych porach roku, nie pomijając kształcenia niedzielno-świątecznego, mają przygotować chłopców i dziewczynki do przyjęcia sakramentów pokuty i bierzmowania.

3. Podobnie i ze szczególną starannościa, każdego dnia Wielkiego Postu i, jeśli byłoby konieczne, w inne dni po świętach Wielkanocnych, mają przygotować właściwymi pouczeniami i refleksjami, małych chłopców i dziewczynki do Pierwszej Komunii świętej.

4. We wszystkich i w poszczególnych parafiach eryguje się kanonicznie Bractwa Nauki Chrześcijańskiej. Z nich proboszczowie, zwłaszcza w miejscach, gdzie brak jest kapłanów, będą mieć dla nauczania Katechizmu ważnych współpracowników w osobach pobożnych świeckich, którzy będą przyczyniać się do tego zbawiennego i świętego dzieła i do chwały Bożej i zyskując przez to wiele odpustów nadanych przez papieża.

5. W większych miastach, zwłaszcza w tych, gdzie jest uniwersytet, licea, szkoły średnie, ustanawia się Szkoły Religii, przeznaczone do nauczania prawd wiary i praktyki życia chrześcijańskiego młodzieży uczęszczającej do szkół publicznych, w których jest zakazane wszelkie nauczanie religijne ${ }^{21}$.

6. Biorąc pod uwagę, że także dorośli nie mniej niż dzieci potrzebują kształcenia religijnego, wszyscy proboszczowie i każdy zajmujący się duszpasterstwem, poza zwykłą homilią opartą na Ewangelii, która ma być wygłaszana we mszy parafialnej we wszystkie święta, będą wyjaśniać wiernym katechizm w sposób łatwy i stosownie do inteligencji słuchaczy, w czasie największej frekwencji ludu, jednak poza czasem, w którym poucza się dzieci. Należy używać Katechizmu Trydenckiego i postępować w następującym porządku: w ciągu czterech lub pięciu lat ukazać wszystkie zagadnienia Symbolu, Sakramentów, Dekalogu, modlitwy niedzielnej i przepisów kościelnych ${ }^{22}$.

Według Acerbo nimis obowiązki proboszczów w kwestiach katechetycznych mają być egzekwowane przez biskupa diecezjalnego. Mocą swojej władzy ma on nadzorować i zapobiegać, aby nie zapominano o wymie-

${ }^{21}$ Por. S. Álvarez Avello, La educación católica en las escuelas. Aspectos canónicos de la relación de la jerarquía de la Iglesia con las escuelas, Romae 2008, s. 31.

${ }^{22}$ Pius PP. X, Litterae encyclicae Acerbo nimis, nr 13. 
nionych przepisach, co przyczyniłoby się do pobieżnego i niesumiennego prowadzenia katechezy ${ }^{23}$.

Kodeks Prawa Kanonicznego z 1917 r. ${ }^{24}$, ogłoszony za pontyfikatu Benedykta XV, przejął ustawodawstwo odnoszące się do katechezy od Soboru Trydenckiego aż do encykliki Acerbo nimis Piusa X, stwarzając przez to podstawy dla dalszego rozwoju nauczania katechetycznego ${ }^{25}$.

Po promulgacji Kodeksu, Święta Kongregacja Soboru w okólniku przesłanym ordynariuszom Włoch poprosiła ich, aby przesłali sprawozdania odnoszące się do przestrzegania przepisów KPK w zakresie katechezy ${ }^{26}$. Odpowiedzi potwierdziły potrzebę lepszej organizacji katechezy oraz postulowały utworzenie centralnego organu kompetentnego w tej materii ${ }^{27}$. Na ten postulat odpowiedział papież Pius XI, który prowadził intensywną działalność prawodawczą w sprawach katechezy. Już w 1923 r. ogłosił motu proprio Orbem catholicum ${ }^{28}$, na mocy którego powołał do życia w Świętej Kongregacji Soboru Officio catechistico - centralę odpowiedzialną za koordynację i wspieranie katechezy na całym świecie ${ }^{29}$. Urząd ten według tego dokumentu zbiera m.in. wiadomości o działalności katechetycznej w diecezjach $\mathrm{w}$ trzech sektorach: nauczanie doktryny chrześcijańskiej w parafiach, w szkołach katolickich i w szkołach publicznych ${ }^{30}$.

Znając ze wspomnianych wyżej sprawozdań ordynariuszy diecezji włoskich stan religijności ludności włoskiej, Pius XI w 1929 r. polecił utworzenie we wszystkich diecezjach Włoch diecezjalnych Urzędów katechetycznych ${ }^{31}$.

${ }^{23}$ Tamże, nr 14. Encyklika Acerbo nimi domaga się także gruntownego i wszechstronnego przygotowania katechetów (nawet większego od kaznodziejów), które powinno być tym bardziej pogłębione, im bardziej słuchacze są mniej wykształceni. Tamże, nr 15.

${ }^{24}$ Codex Iuris Canonici auctoritate Pii X Pontificis Maximi iussu digestus. Benedicti Papae XV auctoritate promulgatus (27 maii 1917), "Acta Apostolicae Sedis" 9 (1917), part II, s. 2-523 (dalej: KPK 1917).

${ }_{25}$ Por. PS, s. 147. KPK 1917 katechezie poświęca księgę III, tytuł XX, rozdział I, kan. 1329-1336.

${ }^{26}$ Benedykt XV po promulgacji Kodeksu ustanowił specjalną komisję, której zlecił opracowanie jednolitego kwestionariusza. Zob. P. Palazzini, L'opera svolta dalla S. Congregazione per il Clero nel campo catechistico, [w:] Sacra Congregazione per il Clero, Atti del II Congresso Catechistico Internazionale (Roma 20-25 settembre 1971), Roma 1972, s. 192.

${ }^{27}$ Gil García A., Documentos oficiales para la Catequesis, nr I, http://www.mercaba.org/ Catequetica [dostęp: 12.10 .2015 r.].

${ }_{28}$ Pius PP. XI, Lettera Apostolica in forma di motu proprio Orbem catholicum (23 iunii 1923), "Acta Apostolicae Sedis" 1923, s. 327-329.

${ }_{29}$ Tamże, s. 327-328.

30 Zob. tamże, s. 328-329.

${ }^{31}$ PS, s. 151; por. G. Biancardi, E. Genre, Catechesi e catechismo nell'Italia unita, http:// www.treccani.it/enciclopedia/catechesi-e-catechismo-nell-italia-unita [dostęp: 12.10.2015 r.]. 
Wreszcie na mocy dekretu Świętej Kongregacji Soboru Provido sane consilio zostaje ustanowiony we wszystkich diecezjach Kościoła Referat katechetyczny (Officium catechisticum) ${ }^{32}$, jako „narzędzie, którym posługuje się biskup - głowa wspólnoty i wykładowca nauki - dla kierowania całą działalnością katechetyczną w diecezji" ${ }^{33}$.

\section{Obowiązek powołania diecezjalnego Wydziału katechetycznego}

Mimo że aktualny Kodeks Prawa Kanonicznego nie wspomina o diecezjalnym Wydziale katechetycznym, to jawi się on jako obowiązkowy. Direttorio Generale per la Catechesi przypomina expressis verbis, że „każda diecezja musi posiadać własny Referat katechetyczny"34. Autorzy powołują się na Ogólną Instrukcję Katechetyczną z 1971 r., gdzie wyraźnie podkreśla się obowiązek istnienia wspomnianego urzędu ${ }^{35}$. KPK mówi jedynie pośrednio o diecezjalnym Wydziale katechetycznym w kan. $775 \S 1$, gdzie prawodawca nakazuje biskupowi zachowywanie przepisów wydanych przez Stolicę Apostolską odnośnie do katechezy ${ }^{36}$.

Dyrektorium Incontriamo Gesù. Orientamenti per l'annuncio e la catechesi in Italia postanawia, że „żaden kościół miejscowy nie może być pozbawiony swojego urzędu katechetycznego" ${ }^{\prime 37}$, natomiast redaktorzy Dyrektorium katechetycznego Kościoła Katolickiego w Polsce przypominają że „swoje zadania i obowiązki w odniesieniu do katechezy biskup sprawuje poprzez Referat katechetyczny kurii biskupiej, zwany w niektórych diece-

32 "Acta Apostolicae Sedis” 1935, s. 151; zob. G. Adler, G. Vogeleisen, Un siècle de catéchèse en France 1893-1980. Histoire, déplacements, enjeux, Paris 1981, s. 120.

${ }_{33} \mathrm{DOK}, \mathrm{nr} 265$. Zadaniem Officium catechisticum jest „,kierowanie całą działalnością katechetyczną". Directorium Catechisticum Generale (11 aprilis 1971), nr 126, Libreria Editrice Vaticana 1971, tekst polski: Ogólna Instrukcja Katechetyczna, „Wiadomości Archidiecezjalne Warszawskie" 1973, nr 2, s. 37-112 (dalej: DCG).

${ }^{34} \mathrm{Nr}$ 267. Warto zauważyć, że dekret Provido sane Consilio („Acta Apostolicae Sedis" 1935, s. 151) postanawiał, że wydział katechetyczny ma być powołany w diecezji „,jeśli to możliwe" (,si fieri poterit"), podczas gdy oba dyrektoria katechetyczne domagają się tej instytucji kategorycznie i bezwarunkowo. DCG, nr 126; DOK, nr 267.

${ }^{35}$ DCG, nr 126.

${ }^{36}$ DOK przypis do nr 265.

37 IGO, nr 88. 
zjach Wydziałem katechetycznym, Wydziałem nauki katolickiej, Wydziałem duszpasterstwa dzieci i młodzieży albo jeszcze inaczej"38.

Konferencja Biskupów Francji w swoim dyrektorium katechetycznym mówiąc o biskupie, który jest głową wspólnoty i wykładowcą nauki dla kierowania całą działalnością katechetyczną w diecezji przypomina, że biskup ma obowiązek, biorąc pod uwagę różne możliwości (propozycje), ustalić w diecezji organizację katechizacji. W przypisie do tego fragmentu zacytowano $\mathrm{nr} 267$ DOK, przypominający, że: „,każda diecezja musi posiadać własny Referat katechetyczny"39.

W schemacie księgi III Kodeksu z 1977 r. znajduje się zapis: „w każdej diecezji musi być Referat (Wydział) katechetyczny"40. Jednak już w schematach do KPK z 1980 r. ${ }^{41}$ i z 1982 r. ${ }^{42}$, jak i w obowiązującym Kodeksie, nie ma $\mathrm{w}$ wzmianki o Wydziale katechetycznym ${ }^{43}$. J. Tobin nazywa ten brak „wątpliwym pominięciem” („a questionable omission”). Autor ten pisze, że opuszczenie dyspozycji kan. 27 § 2 schematu z 1977 r. w Kodeksie musi być widziane jako poważna strata, która może utrudniać posługę katechezy w pewnych obszarach, chociaż niektórzy komentatorzy wskazują, iż wspomniane opuszczenie zostawia po prostu obowiązek powołania Referatu wyłącznie biskupowi diecezjalnemu. Jednak wszystkie dokumenty Stolicy Apostolskiej, począwszy od Provido sane, usilnie przy-

${ }^{38}$ Konferencja Episkopatu Polski, Dyrektorium katechetyczne Kościoła Katolickiego w Polsce, nr 137, Warszawa 2001 (dalej: DKKK).

${ }^{39}$ Conference des Évêques de France, Texte national pour l'orientation de la catéchèse en France et principes d'organisation (8 septembre 2006), Paris 2006, tekst niemiecki: Französische Bischofskonferenz, Nationales Dokument zur Orientierung der Katechese in Frankreich Vorschläge zur Organisation des katechetischen Wirkens (8 September 2006), „Stimmen der Weltkirche" 2007, nr 40, http://www.dbk-shop.de/de/Deutsche-Bischofskonferenz/Stimmen-der-Weltkirche [dostęp: 19.10.2015 r.]. Wydawca zaznacza, że "Stimmen der Weltkirche” nie jest dostępny w wersji drukowanej. W numerze 267 DOK przywołuje się także w przypisie nr 112 do punktu 5.2 Texte national, gdzie przypomina się, że do właściwej organizacji, promocji i kierowania całością katechizacji w ramach całościowego planu katechetycznego jest konieczna diecezjalna służba katechetyczna (urząd).

${ }^{40}$ Pontificia Commissio Codici Iuris Canonici Recognoscendo, Schema canonum libri III De ecclesiae munere docendi, Città del Vaticano 1977, tekst polski: E. Sztafrowski (oprac.), Posoborowe Prawodawstwo Kościelne, t. 11, z. 1, Warszawa 1980, nr 21077-21259, s. 286-328, can. $27 \S 2$.

${ }^{41}$ Zob. Schema Codicis Iuris Canonici, Libreria Editrice Vaticana 1980, can. 730.

${ }^{42}$ Zob. Codex Iuris Canonici, Schema novissimum iuxta placita Patrum Commissionis emendatum atque Summo Pontifici praesentatum, Typis Polyglottis Vaticanis 1982, can. 775.

43 Por. J. Tobin, The diocesan Bishop a Catechist, "Studia Canonica” 1984, nr 2, s. 407; por. P. Urso, Il ministero della parola divina: predicazione e catechesi (cann. 756-780), [w:] La funzione di insegnare della Chiesa, red. Gruppo Italiano Docenti di Diritto Canonico, Milano 1994, s. 45. 
naglają biskupów diecezjalnych do ustanowienia właściwej i skutecznej organizacji katechezy ${ }^{44}$.

W Adhortacji apostolskiej Catechesi tradendae papież Jan Paweł II zaleca biskupom, aby przyjmując podstawową odpowiedzialność za katechezę w diecezji utworzyli urząd koordynujący: „Waszym najważniejszym zadaniem jest wzbudzać i podtrzymywać w diecezjach szczery zapał katechetyczny: chodzi oczywiście o zapał wszczepiony w odpowiednie i skuteczne struktury, obejmujące i wspomagające ludzi, pomoce i urządzenia a także konieczne fundusze" ${ }^{\prime 45}$.

J. Tobin pisze, że argumentacja, iż konieczność istnienia urzędu katechetycznego w każdej diecezji jest przesadą, stanowi niezrozumienie pierwszeństwa katechezy w życiu i misji Kościoła, gdyż bez takiego biura działalność koordynująca biskupa byłaby poważnie utrudniana. Właśnie w każdej diecezji musi być jakaś osoba (osoby) szczególnie kompetentna, wyznaczona przez biskupa, aby promować i koordynować katechezę oraz współpracować $\mathrm{z}$ podobnymi organizacjami $\mathrm{w}$ regionie ${ }^{46}$.

Można oczywiście wskazywać, że zasada podana w kan. 775 § $1 \mathrm{KPK}$, iż biskup diecezjalny winien zachowywać przepisy wydane przez Stolicę Apostolska, może oznaczać, że przez wspomniane opuszczenie kwestii Officium catechisticum prawodawca odsyła do Directorium Catechisticum Generale, gdzie zdecydowanie nalega się na potrzebę istnienia urzędu katechetycznego w każdej diecezji. Ten argument ma pewną wartość i może być sposobem ominięcia tego opuszczenia. Jednak z powodu braku wyraźnego kanonu traktującego o diecezjalnym urzędzie katechetycznym, kwestia jego istnienia może być postrzegana przez niektórych interpretatorów prawa jako nieistotna ${ }^{47}$.

Trzeba zauważyć, że Kodeks Kanonów Kościołów Wschodnich wziął pod uwagę niezmienne stanowisko Stolicy Apostolskiej w sprawie Officium catechisticum, uznając potrzebę eparchialnego urzędu katechetycznego, poprzez który biskup kierowałby nauczaniem katechetycznym w diecezji: „Do biskupa eparchialnego należy z największą troską podejmowanie, kierowanie i rządzenie nauczaniem katechetycznym we własnej eparchii. W tym celu w kurii eparchialnej powinno istnieć eparchialne centrum katechetyczne" ${ }^{\prime 4}$. Należy skonkludować, że w każdej diecezji Referat katechetyczny jest obowiązkowy. Potwierdza to nie tylko doktryna kano-

44 Tamże.

${ }^{45} \mathrm{CT}, \mathrm{nr} 63$.

46 J. Tobin, The diocesan Bishop a Catechist, s. 409.

47 Tamże.

${ }^{48}$ Codex Canonum Ecclesiarum Orientalium. Auctoritate Ioannis Pauli PP. II promulgatus, "Acta Apostolicae Sedis" 1990, s. 1033-1363, tekst polski: L. Adamowicz, M. Dyjakowska, 
nistyczna ${ }^{49}$, ale nade wszystko Direttorio Generale per la Catechesi (opublikowane po promulgacji KPK) ${ }^{50}$, gdzie przypis do nr 265 brzmi: „DCG (1971) 126. Referat katechetyczny (Officium catechisticum) został ustanowiony we wszystkich diecezjach dekretem Provido sane: Św. Kongregacja Soboru, dekret Provido sane (12 stycznia 1935): AAS 27 (1935) 151; por. także KPK, kan. $775 \S 1$ 1”. A więc kan. 775 §1, w myśl którego „przy zachowaniu przepisów wydanych przez Stolicę Apostolska, zadaniem biskupa diecezjalnego jest wydawanie norm odnośnie do katechezy i troska o dostarczenie odpowiednich pomocy katechetycznych, w razie potrzeby również przygotowanie katechizmu, a także popieranie i koordynacja poczynań katechetycznych", zobowiązuje biskupa diecezjalnego do powołania w jego kurii Officium catechisticum. Za obowiązywalnością Referatu katechetycznego w każdej diecezji, na podstawie kan. 775 § 1, świadczą źródła do tego paragrafu, gdzie wyraźnie wymaga się istnienia tego urzędu ${ }^{51}$.

\section{Zadania diecezjalnego Wydziału katechetycznego}

Skoro Officium catechisticum jest obowiązkowe w każdej diecezji, to jakie ma pełnić on zadania? Według dekretu Provido sane consilio urząd ten

Kodeks Kanonów Kościołów Wschodnich, Lublin 2002, kan. 623 § 1-2; por. J. Tobin, The diocesan Bishop a Catechist, s. 409.

49 A. Urru, La funzione di insegnare della Chiesa. Nella legislazione attuale, Roma 2001, s. 66; J. Fuentes, Comentario al can. 775, [w:] A. Marzoa, J. Miras, R. Rodríguez-Ocaña (red.), Comentario exegético al Código de Derecho Canónico, t. 3, cz. I, Pamplona 2002, s. 141. P. Urso (Il ministero della parola divina, s. 45) cytuje wypowiedź T. Bertone: „milczenie Kodeksu [w sprawie urzędu katechetycznego - przyp. J.A.] nie może być interpretowane jako odwołanie dyspozycji [DCG, nr 126 - przyp. J.A.]".

${ }^{50}$ „Katecheza jest działalnością tak podstawową w życiu Kościoła partykularnego, że «każda diecezja musi posiadać własny Referat katechetyczny»". DOK, nr 267.

${ }^{51}$ Jako źródła kan. 775 § 1 wymienia się: Decretum Provido sane Consilio; DCG, nr 126; $\mathrm{CT}, \mathrm{nr}$ 63. Pontificia Commissio Codici Iuris Canonici Authentice Interpretando, Codex Iuris Canonici Auctoritate Ioannis Pauli PP. II promulgatus. Fontium annotatione et indice analitico-alphabetico auctus, Libreria Editrice Vaticana 1989, przypis do kan. $775 \S 1$. Prawodawca powszechny przypomina, że biskup diecezjalny może wydawać przepisy odnoszące się do katechezy, respektując normy Stolicy Apostolskiej w tej materii, a więc określać np. strukturę Referatu Katechetycznego. Congregatio pro Episcopis, Congregatio pro Gentium Evangelizatione, Instructio De Synodis diocesanis agendis (19 marti 1997), „Acta Apostolicae Sedis" 1997, s. 706-721. Additamentum ad instructionem de synodis dioecesanis agendis. Pastoralia munia quae Codex Iuris Canonici concredit legum ferendarum potestati Episcopi dioecesani, I, nr 3, "Acta Apostolicae Sedis” 1997, s. 722-727. Por. F. Ramos, Il sinodo diocesano, „Angelicum” 75 (1998), nr 3, s. 381. 
ma czuwać: aby w parafiach, uczelniach i w kolegiach uczyły osoby odpowiednie, dokładnie wykładając doktrynę chrześcijańską według tradycyjnej (ustalonej) metody Kościoła; aby w ustalonych okresach odbywały się kongresy katechetyczne i inne spotkania odnoszące się do wychowania religijnego, mające na celu dyskusję i studia odnośnie do metod najlepiej odpowiadających katechizacji, o których mówi się w dekrecie tej Świętej kongregacji z 12 kwietnia 1924; aby corocznie odbywały się specjalne kursy religii przygotowujące uczących doktryny chrześcijańskiej w szkołach parafialnych i publicznych, aby wykonywali oni swoje zadania z większą erudycją i doskonałością ${ }^{52}$.

Zgodnie z Directorium Catechisticum Generale „Referat Katechetyczny diecezjalny winien obejmować zespół osób, posiadających właściwą kompetencję. Zakres i różnorodność problemów, nad którymi trzeba się zastanawiać, domaga się rozłożenia odpowiedzialności na wiele osób naprawdę biegłych. Referat diecezjalny winien, również popierać i kierować pracą tych organizacji (jak np.: parafialny ośrodek katechetyczny, bractwo nauki chrześcijańskiej, itd.), które są jakby podstawowymi komórkami działalności katechetycznej. Referat katechetyczny kurii diecezjalnej jest narzędziem, którym posługuje się biskup - głowa wspólnoty i wykładowca nauki - dla kierowania całą działalnością katechetyczną w diecezji" ${ }^{53}$.

Z kolegi Direttorio Generale per la Catechesi odnośnie do zadań omawianego Referatu postanawia: „Do najważniejszych zadań diecezjalnego Referatu katechetycznego należy:

a) Analiza sytuacji diecezjalnej odnośnie do wychowania wiary. W tej analizie należałoby sprecyzować, między innymi, realne potrzeby diecezji w stosunku do praktyki katechetycznej.

b) Opracowanie programu działania, który wskaże jasne cele, zaproponuje kierunki i ukaże konkretne działania.

c) Pomoc katechetom i ich formowanie. $\mathrm{W}$ tym celu należy założyć ośrodki, które uważa się za bardziej odpowiednie.

d) Opracowanie lub przynajmniej wskazanie parafiom i katechetom narzędzi koniecznych dla ich pracy katechetycznej: katechizmy, dyrektoria, programy dla różnych grup wiekowych, przewodniki

${ }^{52}$ PS, pars III, 1, a-c.

53 DCG, nr 126. J. Tobin zauważa (The diocesan Bishop a Catechist, s. 408), że Directorium Catechisticum Generale rozszerzyło kompetencje Diecezjalnego Wydziału Katechetycznego na współpracę z innymi przedsięwzięciami i dziełami apostolskimi, dzięki czemu katecheza nie byłaby odizolowanym resortem (posługą), ale byłaby rozumiana i wykonywana w ramach (w kontekście) całościowo pojmowanego duszpasterstwa. Por. DCG, nr 115, 125. 
dla katechetów, materiały dla katechizowanych, środki audiowizualne...

e) Rozwijanie i popieranie instytucji ściśle katechetycznych w diecezji (katechumenat chrzcielny, katecheza parafialna, grupa odpowiedzialnych za katechezę), które są jakby «podstawowymi komórkami» działalności katechetycznej.

f) Troska przede wszystkim o polepszenie zasobów osobowych i materialnych na poziomie diecezjalnym, parafialnym, jak również dekanalnym.

g) Współpraca z Referatem ds. liturgii, z uwzględnieniem jej istotnego znaczenia dla katechezy, a w szczególności dla katechezy wtajemniczająco-katechumenalnej" 54 .

Według dyrektorium katechetycznego Kościoła we Włoszech Incontriamo Gesù. Orientamenti per l'annuncio e la catechesi in Italia diecezjalny Wydział katechetyczny ma za zadanie: dokonywać analizy sytuacji w diecezji odnośnie do wychowania wiary i sprecyzować m.in. realne potrzeby diecezji w stosunku do praktyki katechetycznej; opracować program działania, w ścisłej łączności ze wskazówkami biskupa, który wskaże jasne cele, zaproponuje kierunki i ukaże konkretne działania; wspierać i formować katechetów, podtrzymując w duchu pomocniczości różne inicjatywy na poziomie diecezjalnym, dekanalnym, parafialnym; opracować własne lub przynajmniej wskazać parafiom i katechetom narzędzia konieczne dla ich pracy katechetycznej: katechizmy, dyrektoria, programy dla różnych grup wiekowych, przewodniki dla katechetów, materiały i różne pomoce; powoływać i popierać instytucje ściśle katechetyczne w diecezji: katechumenat chrzcielny, katechezę parafialną grupę odpowiedzialnych za katechezę; kultywować ścisłą współpracę z regionalną koordynacją katechezy i z Narodowym Urzędem Katechetycznym. Ponadto Wydział katechetyczny pod nadzorem biskupa winien koordynować prace prowadzące do zredagowania albo aktualizacji diecezjalnego programu katechetycznego, rozumianego jako całościowa oferta katechetyczna Kościoła partykularnego, który w sposób systematyczny, spójny i skoordynowany integruje różne procesy katechetyczne proponowane przez diecezję dla adresatów będących w różnym wieku. W tym celu będzie musiał korzystnie współpracować $\mathrm{z}$ organizmami odpowiedzialnymi w diecezji za liturgię, duszpasterstwo rodzin, duszpasterstwo młodzieży, migrantów, miłosierdzia i środków komunikacji ${ }^{55}$.

\footnotetext{
${ }^{54}$ DOK, nr 266.

${ }^{55} \mathrm{IGO}, \mathrm{nr} 88$.
} 
Zgodnie z notą Il Catechismo per l'iniziazione cristiana dei fanciulli e dei ragazzi zadaniem diecezjalnego Wydziału katechetycznego przy współpracy tych, którzy pracują w duszpasterstwie dzieci i młodzieży, jest proponowanie rozwiązań ewentualnych problemów, sprzyjanie integracji różnych składników edukacyjnych w projekcie duszpasterstwa katechetycznego ustalonym w Kościele partykularnym, organizowanie i weryfikowanie formacji katechetów i wychowawców mając na uwadze misję kanoniczną od biskupa ${ }^{56}$.

Natomiast Dyrektorium katechetyczne Kościoła Katolickiego w Polsce postanawia, że Referat katechetyczny działa zgodnie ze statutem nadanym przez biskupa diecezjalnego. Do jego zadań należy przede wszystkim: nadzór merytoryczny i metodyczny nad katechetami, sprawy personalne i organizacyjne dotyczące katechezy zarówno w szkole, jak i w parafii, koordynacja szkolnego nauczania religii z katechezą sakramentalną w parafiach, nadzór nad realizacją w parafiach planu katechetycznego diecezji, uwzględniającego również katechezę dorosłych, nadzór nad organizacją rekolekcji dla dzieci i młodzieży, inspirowanie działań duszpastersko-katechetycznych w diecezji, organizacja kształcenia i dokształcania katechetów, wykonywanie innych zadań zleconych przez biskupa diecezjalnego ${ }^{57}$.

Według Texte national pour l'orientation de la catéchèse en France diecezjalny Wydział katechetyczny może wykonywać swoje zadania tylko w ścisłej współpracy z biskupem, jak również z innymi instytucjami. Urząd ten $\mathrm{w}$ sposób profesjonalny popiera wspólnoty lokalne w zakresie katechizacji, służy materiałami pedagogicznymi, pomaga $\mathrm{w}$ analizie sytuacji katechizacji, w realizacji inicjatyw katechetycznych oraz zapewnia możliwość kształcenia katechetów. Wymieniona służba diecezjalna ma ponadto koordynować różne dzieła, troszczyć się o przepływ informacji oraz organizować współpracę. W razie potrzeby wspiera biskupa przy wyborze materiałów pedagogicznych dla jego diecezji ${ }^{58}$.

Diecezjalny Wydział katechetyczny, jak uzasadniono wyżej, jest obowiązkowym organem kurii diecezjalnej. Zadania tego Wydziału wyeksplikowane w dyrektoriach katechetycznych ogólnokościelnych czy wydanych przez konferencje biskupów nie stanowią wyliczenia taksatywnego

${ }^{56}$ Conferenza Episcopale Italiana, Ufficio Catechistico Nazionale, Nota per l'accoglienza e l'utilizzazione del catechismo della CEI, Il Catechismo per l'iniziazione cristiana dei fanciulli e dei ragazzi (15 giugno 1991), nr 26, „Enchiridion CEI” 1991-1995, vol. 5, s. 80-113.

${ }^{57}$ DKKK, nr 137.

${ }_{58}$ Por. Texte national pour l'orientation de la catéchèse en France et principes d'organisation, nr 5.2. 
(wyczerpującego). Są raczej pewnym zarysem, wskazaniem kierunków działania. Daje to duże możliwości kreacyjne biskupowi diecezjalnemu w dalszym i bardziej szczegółowym określeniu zadań Wydziału, w zależności od potrzeb. Choć Kodeks Prawa Kanonicznego o tym nie wspomina, to jest rzeczą pożądana, aby biskup diecezjalny wydał regulamin dla swojej kurii, określający jej strukturę oraz kompetencje i zadania wchodzących w jej skład organów i osób ${ }^{59}$. Niewątpliwie we wspomnianym regulaminie można by dookreślić także zadania diecezjalnego Wydziału katechetycznego. Wydaje się, że biskup diecezjalny mógłby (a nawet był obowiązany) nadać statut wymienionemu Wydziałowi, o czym świadczy zapis zamieszczony w Dyrektorium katechetycznym Kościoła Katolickiego w Polsce, gdzie mówi się stanowczo, iż „Referat katechetyczny działa zgodnie ze statutem nadanym przez biskupa diecezjalnego" ${ }^{\prime 60}$.

Tytułem przykładu można podać kilka regulacji biskupów diecezjalnych tyczących się zadań Referatu katechetycznego. W diecezji Concordia Pordenone we Włoszech zadaniem omawianego organu kurii jest wspieranie parafii w głoszeniu uaktualnionego i uporządkowanego orędzia ewangelicznego. Stąd stara się on: sprzyjać skutecznemu przekazowi Ewangelii, która także obecnie jest w stanie wzbudzić zainteresowanie i „czynić uczniów" Pana Jezusa oraz uświadamiać wspólnotom prawdę, że każdy wiek i sytuacja życia mogą stać się okazją do ogłoszenia orędzia ewangelicznego i jego pogłębiania. Gdy idzie o zakresy działania Referatu katechetycznego, to prawodawca ukazuje pięć konkretnych obszarów aktywności: katecheza dorosłych, katecheza i wtajemniczenie chrześcijańskie, katecheza niepełnosprawnych, formacja katechetów, apostolat biblijny ${ }^{61}$.

Diecezja Brescia we Włoszech przed swoim Referatem katechetycznym stawia następujące cele i zadania: diecezjalny Wydział katechetyczny w zależności od wikariusza ds. duszpasterstwa świeckich i w powiązaniu z innymi urzędami kurii ma zadanie koordynować, podtrzymać i promować inicjatywy, które już są realizowane albo winny być uruchomione

${ }^{59}$ Por. J. Krukowski, Zasady organizacji i funkcjonowania kurii diecezjalnej, [w:] J. Krukowski, K. Warchałowski (red.), Struktura i zadania kurii diecezjalnej, Warszawa 2003, s. 14. Przykładem regulaminu kurii diecezjalnej, w którym zawarto normy regulujące strukturę i zadania Diecezjalnego Wydziału Katechetycznego jest Regulamin Kurii Diecezjalnej, będący aneksem do statutów Pierwszego Synodu Diecezji Toruńskiej. Uchwaty Pierwszego Synodu Diecezji Toruńskiej. Prawo partykularne Kościoła Toruńskiego, Torun 2011, st. 212, s. 65. Regulamin Kurii Diecezjalnej, st. 29 § 1-2, s. 214, a także diecezja w Cremonie we Włoszech, sufragania Archidiecezji Mediolańskiej. Regolamento della Curia Diocesana, Titolo III, art. 46-47, http://www.diocesidicremona.it [dostęp: 23.10.2015 r.].

${ }^{60}$ DKKK, nr 137.

${ }^{61}$ Por. http://www.diocesi.concordia pordenone.it [dostęp: 10.10.2015 r.]. 
w Diecezji w sektorze ewangelizacji i katechezy, w zależności od decyzji i planów biskupa.

Szczegółowe zadania diecezjalnego Wydziału katechetycznego w diecezji Brescia są następujące: popierać zgodnie z zasadą pomocniczości formację katechetów dzieci, adolescentów, młodzieńców i dorosłych (obejmującą także katechetów katechumenów i katechetów dorosłych kandydatów do bierzmowania); popierać w diecezji pierwszeństwo ewangelizacji i katechezy dorosłych, także poprzez powstanie "Centri di ascolto della Parola di Dio"; koordynować i weryfikować chrześcijańskie wtajemniczenie dorosłych w parafiach; współpracować w promocji apostolatu biblijnego w diecezji; towarzyszyć we wdrażaniu nowego modelu „chrześcijańskiej inicjacji dzieci i młodzieży” poprzez spotkania formacyjne w strefach pastoralnych dla parafialnych i strefowych rad duszpasterskich, prezbiterów i katechetów; podtrzymywać żywą i konkretną uwage parafii skierowaną na formację chrześcijańską osób niepełnosprawnych; współpracować z Narodowym Urzędem Katechetycznym i diecezjalnymi Wydziałami katechetycznymi Lombardii i Włoch ${ }^{62}$.

Diecezja Cremona we Włoszech posiada Regulamin kurii diecezjalnej, gdzie postanawia się, że urząd dla ewangelizacji i katechezy, powierzony dyrektorowi („,odpowiedzialnemu”), promuje i koordynuje akcję ewangelizacyjną i katechetyczną w diecezji wspomagany przez Komisję dla ewangelizacji i katechezy.

Urząd ten ma zadania:

- w ścisłej współpracy z Centrum Studiów i Grupą Badawczą nad religijnością i nowymi sektami, określić ogólny zarys kulturowy i religijny diecezji, w celu określenia potrzeb i dróg ewangelizacji

- popieranie głoszenia orędzia ewangelicznego poprzez kontakty ze światem kultury, promowanie Centri di ascolto $0^{63}$ i innych doświadczeń związanych z zaangażowaniem się na rzecz osób niewierzących.

Na stronie internetowej Diecezji Rafaela w Argentynie, będącej sufraganią archidiecezji Santa Fe de la Vera Cruz zamieszczono informację, że diecezjalny „Wydział katechetyczny jest narzędziem, którym posługuje się biskup - głowa wspólnoty i wykładowca nauki - dla kierowania całą działalnością katechetyczną w diecezji". Główne zadania Wydziału katechetycznego powtórzono za DOK, nr $266^{64}$.

${ }^{62} \mathrm{http} / / /$ www.diocesi.brescia.it [dostęp: 22.10 .2015 r.].

${ }^{63}$ Centro di ascolto: w ramach opieki społecznej Kościoła katolickiego we Włoszech, Centro di ascolto to instytucja powołana do spotkań i pomagająca ludziom żyjącym w sytuacjach trudnych.

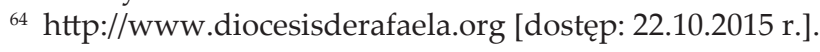


Statuty IV Synodu Archidiecezji Warszawskiej podejmując kwestię katechizacji wskazuja, że Wydział Nauki Katolickiej (Officium catechisticum) nadzoruje, koordynuje i wspiera szkoły katolickie oraz inne powołane w tym celu instytucje. Wydział ten winien współpracować z Wydziałem katechetycznym Konferencji Episkopatu Polski ${ }^{65}$. Wymieniony organ kurii diecezjalnej we współpracy z Wydziałem Duszpasterstwa organizuje skrutynium katechetyczno-duszpasterskie dla księży po pięcioletniej formacji katechetycznej ${ }^{66}$. Wydział Nauki Katolickiej jest kompetentny w sprawach zatrudniania, zwalniania i zmian katechety ${ }^{67}$, udzielania i przedłużania katechecie misji do nauczania ${ }^{68}$, organizuje permanentną formację katechetyczną ${ }^{69}$.

I Synod Archidiecezji Białostockiej postanawia, że Wydział Katechetyczny Kurii współpracuje z proboszczami w zatrudnianiu w parafiach i odpowiednich katechetów świeckich i sióstr zakonnych ${ }^{70}$, pośredniczy w sprawach misji kanonicznej, którą wystawia biskup diecezjalny ${ }^{71}$, organizuje rekolekcje i dni skupienia dla katechetów ${ }^{72}$.

Uchwały Pierwszego Synodu Diecezji Toruńskiej zawierają zapis, według którego „nauczaniem katechetycznym w diecezji kieruje biskup diecezjalny, którego wspomaga Diecezjalna Rada Katechetyczna jako organ doradczy i Wydział katechetyczny Kurii Diecezjalnej z Wydziałem Duszpasterski Kurii Diecezjalnej jako organ wykonawczy"73. Wydział katechetyczny Kurii Diecezjalnej współpracuje z Wydziałem Duszpasterskim Kurii Diecezjalnej w koordynacji duszpasterstwa nauczycieli i pracowników szkół w diecezji ${ }^{74}$. Do zadań Wydziału katechetycznego należą: troska i odpowiedzialność za planowanie, organizację, przebieg i wyniki pracy katechetycznej w diecezji; inicjowanie i organizowanie działań duszpastersko-katechetycznych z dziećmi i młodzieżą we współpracy z Wydziałem Duszpasterskim, w tym czuwanie nad organizacją i prze-

${ }^{65}$ IV Synod Archidiecezji Warszawskiej, Warszawa 2003, st. 139, s. 52. Synod Warszawski błędnie stwierdza, że istnieje Wydział Katechetyczny Konferencji Episkopatu Polski, powołując się przy tym, nie wiadomo czemu, na kan. $774 \mathrm{KPK}$. Istnieje tylko Komisja Wychowania Katolickiego KEP.

${ }^{66}$ Tamże, st. 142, s. 52.

67 Tamże, st. 148 , s. 54 .

68 Tamże, st. 153, s. 54.

${ }^{69}$ Tamże, st. 161, s. 55.

${ }^{70}$ I Synod Archidiecezji Białostockiej, Białystok 2000, st. 172, s. 59.

71 Tamże, st. 183, s. 61.

72 Tamże, st. 185, s. 62.

${ }^{73}$ Uchwaty Pierwszego Synodu Diecezji Toruńskiej, st. 212, s. 65.

${ }^{74}$ Tamże, st. 423 § 4, s. 142. 
biegiem rekolekcji szkolnych; systematyczne przeprowadzanie wizytacji katechetycznych w parafiach oraz sporządzanie z nich protokołów; stała formacja katechetów; koordynowanie prac wizytatorów katechetycznych; organizowanie i opracowywanie pomocy katechetycznych; załatwianie interesantów i korespondencji dotyczących spraw katechetycznych; współorganizowanie spotkań Diecezjalnej Rady Katechetycznej; Wydział koordynuje prace poradnictwa metodycznego oraz współpracuje z działającymi w diecezji ekspertami Ministerstwa Edukacji Narodowej ds. katechezy szkolnej ${ }^{75}$.

Z kolei Pierwszy Synod Diecezji Rzeszowskiej stwierdza, że w diecezji rzeszowskiej działalność katechetyczną w imieniu biskupa diecezjalnego koordynuje Wydział katechetyczny kurii diecezjalnej ${ }^{76}$. Do zadań Wydziału katechetycznego należą przede wszystkim: nadzór merytoryczny i opieka metodyczna nad katechetami; prowadzenie dokumentacji stanu katechizacji w Diecezji; opracowywanie i realizacja programu formacji stałej dla katechetów świeckich i sióstr zakonnych; troska o pomoce formacyjne dla katechizowanych i katechizujących; współpraca z proboszczami; wszechstronna współpraca oraz koordynacja zadań podejmowanych przez wizytatorów, katechetyczny zespół metodyczny oraz ekspertów ds. awansu zawodowego katechetów; koordynacja współpracy z oświatowymi organami państwowymi i samorządowymi; współpraca ze wszystkimi agendami diecezjalnymi ${ }^{77}$.

Synod Archidiecezji Warmińskiej postanawia, że Wydział Nauki Katolickiej określa szczegółowy program nauczania oraz rodzaje podręczników dla całej archidiecezji ${ }^{78}$, gromadzi ankiety katechetyczne przekazywane przez proboszczów ${ }^{79}$, a także pełni nadzór merytoryczny nad nauczycielami religii ${ }^{80}$, jak również organizuje rekolekcje i konferencje metodyczne dla nauczycieli religii ${ }^{81}$.

75 Tamże, Regulamin Kurii Diecezjalnej, st. 29 § 1-2, s. 214.

${ }^{76}$ Pierwszy Synod Diecezji Rzeszowskiej, Rzeszów 2004, st. 172, s. 105.

77 Tamże, st. 172 § 3, s. 105.

78 I (XIV) Synod Archidiecezji Warmińskiej (2006-2012). Misja Kościoła Warmińskiego w dziele Nowej Ewangelizacji, Olsztyn 2012, st. 269, s. 66.

79 Tamże, st. 271, s. 66.

${ }^{80}$ Tamże, st. 277, s. 67.

81 Tamże, st. 278, s. 67. 


\section{Wnioski}

Z przeprowadzonych rozważań i analiz należy wyciągnąć następujące wnioski:

1. Mimo że aktualny Kodeks Prawa Kanonicznego nie wspomina o Referacie (Wydziale) katechetycznym w diecezji, to w świetle Directorium Catechisticum Generale z 1971 r. i aktualnego Direttorio Generale per la Catechesi z 1997 r. jawi się on jako obowiązkowy w każdej diecezji.

2. Diecezjalny Wydział katechetyczny jest istotnym elementem organizacji nauczania katechetycznego w diecezji.

3. Prawo partykularne, szczególnie synody diecezjalne, winno zagwarantować istnienie Officium catechisticum w diecezji (zwłaszcza że KPK o tym milczy), powołując się zarówno na kan. 775 § 1 KPK, jak i na aktualne Dyrektorium Ogólne o Katechizacji.

4. Warto, aby Referat katechetyczny posiadał swój statut nadany przez biskupa diecezjalnego, jak też był określony w regulaminie kurii diecezjalnej.

5. Biskup diecezjalny, respektując normy Stolicy Apostolskiej, winien ustalić strukturę Referatu katechetycznego i zakres jego zadań.

6. Referat katechetyczny ma pozostawać w ścisłej relacji z biskupem diecezjalnym i innymi agendami kurii diecezjalnej.

7. Diecezjalny Wydział katechetyczny winien współpracować ze swoimi odpowiednikami z innych diecezji, jak i z odpowiednią agendą (urzędem, komisją) konferencji episkopatu, celem ujednolicenia posługi katechetycznej na danym obszarze.

Słowa kluczowe: Diecezjalny wydział katechetyczny, katechizacja, biskup diecezjalny, statut, Dyrektorium ogólne o katechizacji

\section{Bibliografia}

Adler G., Vogeleisen G., Un siècle de catéchèse en France 1893-1980. Histoire, déplacements, enjeux, Paris 1981.

Álvarez Avello S., La educación católica en las escuelas. Aspectos canónicos de la relación de la jerarquía de la Iglesia con las escuelas, Romae 2008.

Biancardi G., Genre E., Catechesi e catechismo nell'Italia unita, http://www. treccani.it/enciclopedia/catechesi-e-catechismo-nell-italia-unita [dostęp: 12.10.2015 r.] 
Gil García A., Documentos oficiales para la Catequesis, http://www.mercaba.org/ Catequetica [dostęp: 12.10.2015 r.].

Krukowski J., Zasady organizacji i funkcjonowania kurii diecezjalnej, [w:] J. Krukowski, K. Warchałowski (red.), Struktura i zadania kurii diecezjalnej, Warszawa 2003, s. 11-26.

Palazzini P., L'opera svolta dalla S. Congregazione per il Clero nel campo catechistico, [w:] Sacra Congregazione per il Clero, Atti del II Congresso Catechistico Internazionale, (Roma 20-25 settembre 1971), Roma 1972, s. $147-212$.

Ramos F., Il sinodo diocesano, „Angelicum” 1998, nr 3, s. 359-401.

Tobin J., The diocesan Bishop a Catechist, „Studia Canonica” 1984, nr 2, s. 365414.

Urru A., La funzione di insegnare della Chiesa. Nella legislazione attuale, Roma 2001.

Urso P., Il ministero della parola divina: predicazione e catechesi (cann. 756-780), [w:] La funzione di insegnare della Chiesa, (red.) Gruppo Italiano Docenti di Diritto Canonico, Milano 1994, s. 25-49.

\section{THE DIOCESAN CATECHETICAL OFFICE}

\section{S u m m a r y}

This article aims to present the diocesan catechetical office and its tasks. In the first part, the history of the creation of the diocesan catechetical office is depicted. The second part highlights an obligation to appoint a diocesan catechetical department, and the third part is dedicated to the tasks of such an institution.

Key words: diocesan catechetical office, catechetical activity, diocesan Bishop, statute, General directory for catechesis

\section{ЕПАРХИАЛЬНОЕ КАТЕХИЧНОЕ УЧРЕЖДЕНИЕ}

$$
\text { P е } 3 \text { ю м е }
$$

Целью статьи является показ епархиального катехичного учреждения и его заданий. В первой части представдена история возникновения епархиального катехичного учреждения. В другой части указаны обязанность призвания епархиального катехичного отдела, хотя третья часть была посвящена заданиям упомянутого учреждения.

Ключевые слова: Епархиальный катехичный отдел, катехизис, епархиальный епископ, устав, Общей директ о катехизис 